\title{
Repurposing of anticancer drugs: in vitro and in vivo activities against Schistosoma mansoni
}

Noemi Cowan ${ }^{1,2}$ and Jennifer Keiser ${ }^{1,2^{*}}$

\begin{abstract}
Background: Drug discovery for the neglected tropical disease schistosomiasis has a high priority. Anticancer drugs, especially protein kinase inhibitors, might serve as a starting point for drug discovery owing to the importance of protein kinases in helminth growth and development. Furthermore, the Schistosoma mansoni genome encodes several genes for targets of drugs marketed for human use, including several anticancer drugs.

Methods: In this study, we screened the approved oncology drug set of the National Cancer Institute's Developmental Therapeutic Program for antischistosomal activity. Drugs were tested in vitro against the larval and adult stage of $S$. mansoni. $\mathrm{IC}_{50}$ values and albumin binding were determined for active compounds. Lead compounds were tested in the chronic S. mansoni mouse model.

Results: Eleven of the 114 compounds tested revealed $I_{50}$ values $\leq 10 \mu \mathrm{M}$ against both $S$. mansoni stages. Five of these lost activity against adult S. mansoni in the presence of serum albumin. Of 6 compounds studied in vivo, the highest activity was observed from two kinase inhibitors trametinib, and vandetanib, which reduced worm burden by 63.6 and $48.1 \%$ respectively, after a single oral dose of $400 \mathrm{mg} / \mathrm{kg}$ body weight.

Conclusion: Our study has confirmed that oncology drugs possess antischistosomal activity. There is space for further investigation, including elucidation of the mechanisms of action of schistosome-active cancer drugs, application of different treatment courses, and structure-activity relationship studies for improving drug potency.
\end{abstract}

Keywords: Schistosomiasis, Drug repurposing, Drug screening, Protein kinase inhibitor

\section{Background}

Schistosomiasis is a neglected tropical disease caused by the blood-dwelling fluke of the genus Schistosoma. The clinically relevant species are S. mansoni, S. haematobium, and S. japonicum. Approximately 779 million people live at risk of infection, and 230 million are infected [1], causing an estimated 3.3 million disability-adjusted life years (DALYs) [2]. Praziquantel is the sole treatment against all three species. The lack of drugs in the discovery pipeline highly encourages efforts to identify an alternative treatment of schistosomiasis, in anticipation of praziquantel resistance [3, 4]. Drug repurposing is an efficient tool to find new drugs against helminthiases, reducing time and costs of drug research and development [5].

In recent years, imatinib $\left(\right.$ Gleevec $\left.^{\circ}\right)$, a kinase inhibitor used to treat chronic myeloid leukemia, gained attention in

\footnotetext{
* Correspondence: jennifer.keiser@unibas.ch

${ }^{1}$ Department of Medical Parasitology and Infection Biology, Swiss Tropical and Public Health Institute, P.O. Box, CH-4002, Basel, Switzerland

${ }^{2}$ University of Basel, P.O. Box, $\mathrm{CH}-4003$, Basel, Switzerland
}

the field of antischistosomal drug research due to its doseand time-dependent effect on S. mansoni in vitro [6]. It has been observed that imatinib causes degenerative changes in the gonads and gastrodermis of schistosomes [7]. Furthermore, protein kinase inhibitors interfere with essential developmental steps in the biology of schistosomes $[6,8]$.

We have recently identified $N, N^{*}$-diarylureas as a new chemical class potent against S. mansoni [9]. A subsequent structure-activity relationship (SAR) study revealed $N, N^{\prime}$-diarylureas and $N$-phenyl benzamides as the relevant pharmacophores for antischistosomal drug activity [10]. These pharmacophores are also present in some marketed anticancer drugs, such as sorafenib and ponatinib.

The Developmental Therapeutics Program (DTP) of the National Cancer Institute (NCI) (USA) offers drug repositories free of charge to endorse preclinical research (https://dtp.nci.nih.gov/repositories.html); among which is a set of the US Food and Drug Administration (FDA)-approved anticancer drugs.

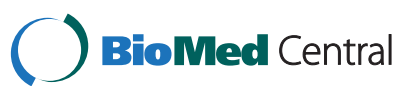

(C) 2015 Cowan and Keiser. Open Access This article is distributed under the terms of the Creative Commons Attribution 4.0 International License (http://creativecommons.org/licenses/by/4.0/), which permits unrestricted use, distribution, and reproduction in any medium, provided you give appropriate credit to the original author(s) and the source, provide a link to the Creative Commons license, and indicate if changes were made. The Creative Commons Public Domain Dedication waiver (http://creativecommons.org/publicdomain/zero/1.0/) applies to the data made available in this article, unless otherwise stated. 
There are 54 drugs for human use on the market which exert their pharmacological effect on 26 drug targets which are also encoded by the genome of $S$. mansoni [11]. Fourteen of those drugs are part of DTP's oncology drug set.

The aim of this study was to evaluate DTP's oncology drug set of 114 FDA-approved drugs for antischistosomal activity. We tested the drugs first on the larval stage of $S$. mansoni (schistosomula), followed by screening of larvaeactive compounds against adult worms. $\mathrm{IC}_{50}$ values were then determined against adult $S$. mansoni, and the influence of protein binding on drug activity was assessed using physiological amounts of serum albumin. The most active compounds were subsequently tested in $S$. mansoni-infected mice.

\section{Methods}

\section{Drugs and media}

The cancer drug library used for schistosome in vitro assays was gratefully received in June 2014 from the DTP/NCI as $10 \mathrm{mM}$ stock solutions $(20 \mu \mathrm{l})$ in dimethyl sulfoxide (DMSO) in 96-well plates. Hit compounds were ordered as solid compounds from DTP, and dissolved in DMSO to $10 \mathrm{mM}$ stock solutions. Bosutinib was not available from DTP and was therefore purchased from Sigma-Aldrich. For in vivo studies, solid afatinib, bosutinib, ponatinib, trametinib, and vandetanib were purchased from AkScientific. Sunitinib was purchased from VWR as a $100 \mathrm{mM}$ solution in DMSO.

Medium 199, and RPMI 1640 were purchased from Life Technologies. Heat-inactivated fetal calf serum (FCS), penicillin, and streptomycin were purchased from LuBioScience.

\section{Mouse infection and maintenance}

Rodent experiments were authorized by the Canton Basel-Stadt, Switzerland (license no. 2070).

Female NMRI mice, 3-weeks of age, were purchased from Charles Rivers, Germany. After a 1-week adaptation period, mice were infected with cercariae collected from $S$. mansoni-infected intermediate host snails (Biomphalaria glabrata), by subcutaneous injection with 100 cercariae [12]. Mice received rodent food and water ad libitum and were maintained with a 12-h light/dark cycle, at $22{ }^{\circ} \mathrm{C}$ and $50 \%$ humidity.

\section{Larval schistosome drug assay}

$S$. mansoni cercariae were collected from S. mansoni-infected B.glabrata, and mechanically transformed to newly transformed schistosomula (NTS) [13]. After a resting period of $12-24 \mathrm{~h}\left(37^{\circ} \mathrm{C}, 5 \% \mathrm{CO}_{2}\right)$, drugs were tested for NTS activity at a concentration of $33.3 \mu \mathrm{M}$ in Medium 199 supplemented with $5 \%$ FCS, $200 \mathrm{U} / \mathrm{ml}$ penicillin, and $200 \mu \mathrm{g} / \mathrm{ml}$ streptomycin, and prepared in 96-well flatbottom plates with 100 NTS per well. NTS incubated with the equivalent volume of drug-free DMSO (0.3 \%) served as control. NTS were evaluated 24, 48, and $72 \mathrm{~h}$ after incubation via microscopic read out (80-120x magnification; Zeiss; Germany), using a scoring scale from 3 (normal viability, morphology, and granularity) to 0 (no motility, changed morphology, and granularity). Drugs with an activity of $\geq 50 \%$ after $24 \mathrm{~h}$, and/or $90 \%$ after $72 \mathrm{~h}$, and a drug effect on adult schistosomes of $\geq 80 \%$ after $24 \mathrm{~h}$ and/or $90 \%$ after $72 \mathrm{~h}$ at $33.3 \mu \mathrm{M}$, were tested at six different concentrations ranging from 0.14 to $33.3 \mu \mathrm{M}$ using a 3fold dilution series for $\mathrm{IC}_{50}$ determination. All assays were performed in duplicate and repeated once [10].

\section{Adult schistosome drug assay}

Adult schistosomes were collected from mice with a chronic S. mansoni infection (7-week-old) by dissection of the mesenteric veins. Drugs were tested at $33.3 \mu \mathrm{M}$ in RPMI 1640 culture medium supplemented with $5 \%$ FCS, $100 \mathrm{U} / \mathrm{ml}$ penicillin, and $100 \mu \mathrm{g} / \mathrm{ml}$ streptomycin, and prepared in 24-well flat-bottom plates. Three flukes of both sexes were put into the wells, incubated at $37{ }^{\circ} \mathrm{C}$, and $5 \%$ $\mathrm{CO}_{2}$, and scored (in the same manner as described for NTS) after 1, 24, 48, and $72 \mathrm{~h}$. Drugs revealing activity against NTS, and adult schistosomes (as explained above), were assessed for their $\mathrm{IC}_{50}$, using 3 -fold serial dilutions resulting in five different concentrations ranging from 0.41 to $33.3 \mu \mathrm{M}$, and scored $4,24,48$, and $72 \mathrm{~h}$ post incubation. $\mathrm{IC}_{50}$ determinations were performed in duplicate, and repeated once [12]. For compounds exhibiting an $\mathrm{IC}_{50}<33.3 \mu \mathrm{M}, \mathrm{IC}_{50} \mathrm{~S}$ were determined using culture medium supplemented with $45 \mathrm{~g} / \mathrm{l}$ bovine serum albumin (AlbuMax II Lipid-Rich BSA, Gibco): the physiological albumin concentration in humans [14].

\section{Preclinical and clinical data from FDA and EMA}

FDA and European Medicines Agency (EMA) data sheets were used to retrieve drug information such as the maximal plasma concentration $\left(C_{\max }\right)$, plasma half-life $\left(t_{1 / 2}\right)$, nonclinical toxicology (lethal single oral dose $\mathrm{LD}_{50}$ ), indication, mechanism of action, and dosage.

\section{In vivo adult schistosome drug assay}

For oral application, the drugs were dissolved in $7 \%$ Tween 80 and $3 \%$ ethanol in water $(\mathrm{v} / \mathrm{v} / \mathrm{v})$, with the exception of sunitinib, which was used as obtained. Groups of 4 mice harboring a chronic S. mansoni infection were treated with a single oral dose of $400 \mathrm{mg} / \mathrm{kg}$ body weight, or $200 \mathrm{mg} / \mathrm{kg}$ for afatinib due to its low $\mathrm{LD}_{50}(382-763 \mathrm{mg} / \mathrm{kg}$ in mice) [15]. A control group of 8 mice was left untreated. Three weeks post treatment, the mice were euthanized, and schistosomes residing in the mesenteric veins and the liver were counted and sexed. 


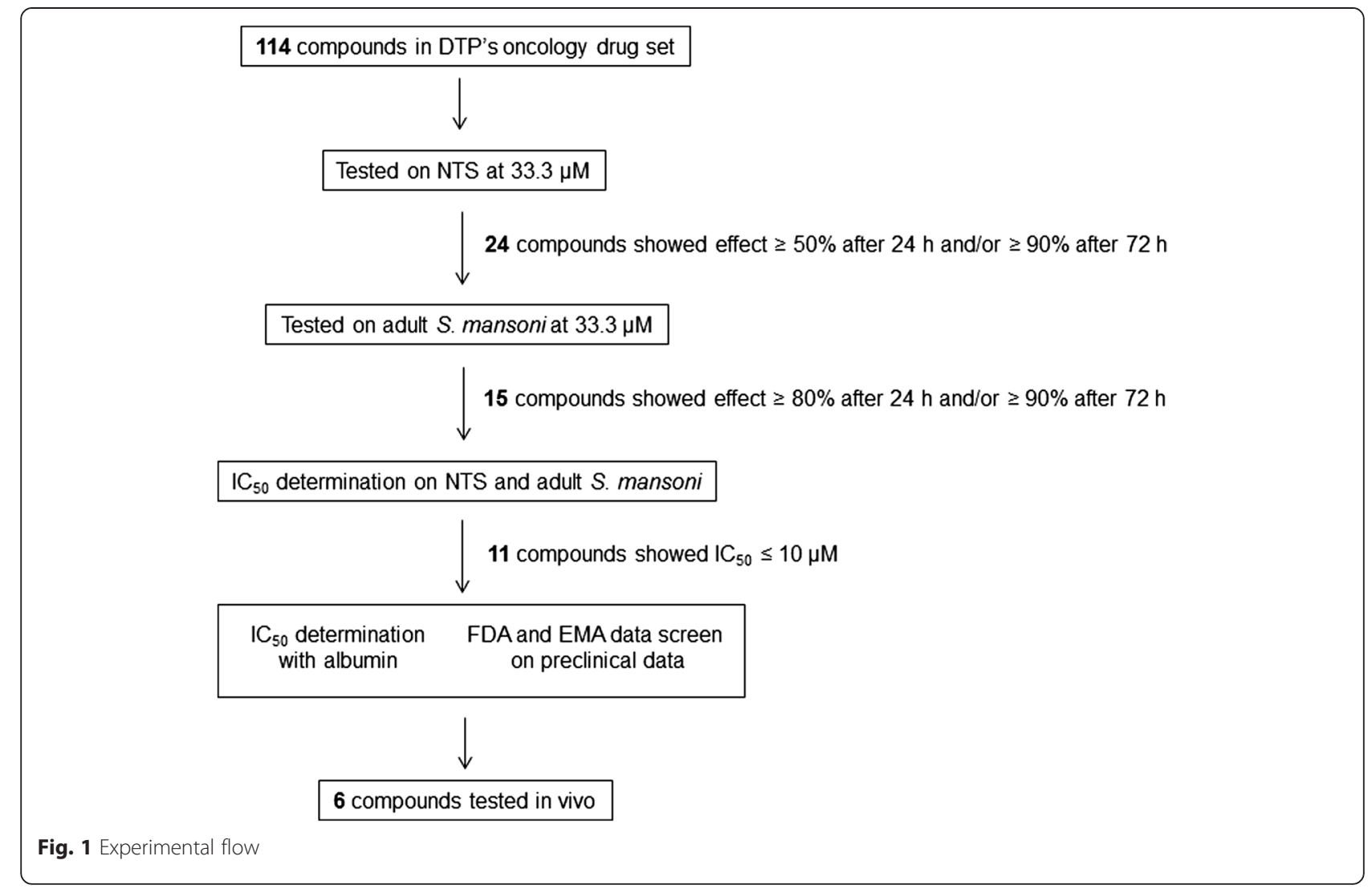

Table $1 I_{50}$ values of anticancer drugs against larval (NTS) and adult stages of S. mansoni

\begin{tabular}{llll}
\hline Compound & $\begin{array}{l}\text { NTS: } I C_{50} \\
\text { value }[\mu \mathrm{M}]\end{array}$ & $\begin{array}{l}\text { Adult S. } \\
\text { mansoni: } \\
I_{50} \\
\text { value } \\
{[\mu \mathrm{M}]}\end{array}$ & $\begin{array}{l}\text { Adult S. mansoni: } \mathrm{IC}_{50} \\
\text { value in the presence } \\
\text { of albumin }[\mu \mathrm{M}]\end{array}$ \\
\hline Regorafenib & 6.9 & 1.0 & $>>33.3$ \\
Ponatinib & 0.2 & 1.1 & 20.2 \\
Sorafenib & 4.1 & 1.1 & $>>33.3$ \\
Bosutinib & 0.8 & 1.5 & 14.8 \\
Afatinib & 0.8 & 1.8 & 9.9 \\
Sunitinib & 1.0 & 1.8 & 10.6 \\
Crizotinib & 0.3 & 2.3 & 18.8 \\
Trametinib & 4.6 & 4.1 & 21.0 \\
Tamoxifen citrate & 2.0 & 5.7 & $>>33.3$ \\
Gefitinib & 7.8 & 8.3 & $>>33.3$ \\
Cabozantinib & 19.3 & 9.0 & $>>33.3$ \\
Celecoxib & 41.9 & 9.4 & $>>33.3$ \\
Vandetanib & 0.9 & 9.5 & $>>33.3$ \\
Idarubicin $\mathrm{HCl}$ & 12.7 & 16.2 & $>>33.3$ \\
Mechlorethamine $\mathrm{HCl}$ & $>>33.3$ & 84.8 & Not done \\
\hline
\end{tabular}

\section{Statistics}

Drug effects on schistosomes were determined with the scores of parasites exposed to drug, and the score of the controls. For $\mathrm{IC}_{50}$ and $\mathrm{r}$ value (linear correlation coefficient) determination, the dose-response was calculated with CompuSyn (version 3.0.1; ComboSyn), as described previously [10]. In vivo worm burden reductions (WBR) were calculated with the number of worms found in treated mouse groups compared to the control group [10]. $P$-values were calculated using the Kruskal-Wallis test (Stats direct statistical software version 2.8.0).

\section{Results \\ In vitro studies \\ In vitro activities against NTS}

DTP's oncology drug set was first tested at $33.3 \mu \mathrm{M}$ against NTS (Fig. 1). Twenty-four drugs showed an effect $\geq 50 \%$ after $24 \mathrm{~h}$, and/or $\geq 90 \%$ after $72 \mathrm{~h}$. The most active drugs were crizotinib, ponatinib, and tamoxifen citrate, killing NTS in less than $1 \mathrm{~h}$. Afatinib, idarubicin hydrochloride, regorafenib, sorafenib, and temsirolimus were lethal to NTS within $24 \mathrm{~h}$, everolimus and sirolimus within $48 \mathrm{~h}$, and bosutinib, daunorubicin, and vandetanib within $72 \mathrm{~h}$ (Table 1 ). 
In vitro activities against adult S. mansoni

The 24 NTS-active compounds were subsequently tested on adult S. mansoni at $33.3 \mu \mathrm{M}$. Tamoxifen citrate was the most active compound, killing all adult worms within $1 \mathrm{~h}$. Afatinib, ponatinib, and sorafenib caused death of all adults within $24 \mathrm{~h}$, whereas adult worms incubated with bosutinib and idarubicin hydrochloride were dead after $72 \mathrm{~h}$. In total, 15 compounds were classified as active against adult S. mansoni, characterized by an effect $\geq 80 \%$ after $24 \mathrm{~h}$, and/or $\geq 90 \%$ after 72 h (Table 1).

\section{Determination of $\mathrm{IC}_{50}$ values}

These 15 compounds were investigated further by assessing their $\mathrm{IC}_{50}$ values against adult worms and NTS.
Eleven compounds (structures depicted in Table 2) revealed high activities $\left(\mathrm{IC}_{50} \leq 10 \mu \mathrm{M}\right)$ against both stages after $72 \mathrm{~h}$.

However, $\mathrm{IC}_{50}$ values increased in the presence of albumin. In medium supplemented with $45 \mathrm{~g} / \mathrm{L}$ BSA, only 6 compounds showed activity $\left(\mathrm{IC}_{50}\right.$ of $9-21 \mu \mathrm{M}$ against adult $S$. mansoni), namely afatinib, bosutinib, crizotinib, ponatinib, suntinib, and trametinib. For the remaining compounds tested, no $\mathrm{IC}_{50}$ could be calculated due to lack of activity.

\section{Preclinical and clinical data}

Data on pharmacokinetic parameters, toxicity, and other information of interest accessible from the FDA and the EMA (summarized in Table 3) were consulted for the 11

Table 2 Chemical structures of lead compounds<smiles>CN(C)C/C=C/C(=O)Nc1cc2c(Nc3ccc(F)c(Cl)c3)ncnc2cc1OC1CCOC1</smiles>

afatinib<smiles>COc1cc2ncnc(Nc3ccc(F)c(Cl)c3)c2cc1OCCCN1CCOCC1</smiles>

gefitinib<smiles>CNC(=O)c1cc(Oc2ccc(NC(=O)Nc3ccc(Cl)c(C(F)(F)F)c3)cc2)ccn1</smiles><smiles>COc1cc(Nc2c(C#N)cnc3cc(OCCCN4CCN(C)CC4)c(OC)cc23)c(Cl)cc1Cl</smiles>

bosutinib<smiles>Cc1ccc(C(=O)Nc2ccc(CN3CCN(C)CC3)c(C(F)(F)F)c2)cc1C#Cc1cnc2cccnn12</smiles>

ponatinib<smiles>CCN(CC)CCNC(=O)c1c(C)[nH]c(C=C2C(=O)Nc3ccc(F)cc32)c1C</smiles>

sunitinib<smiles>COc1cc2c(Nc3ccc(Br)cc3F)ncnc2cc1OCC1CCN(C)CC1</smiles><smiles>CC(Oc1cc(-c2cnn(C3CCNCC3)c2)cnc1N)c1c(Cl)ccc(F)c1Cl</smiles>

crizotinib<smiles>CC(=O)Nc1cccc(-n2c(=O)n(C3CC3)c(=O)c3c(Nc4ccc(I)cc4F)n(C)c(=O)c(C)c32)c1</smiles>

tamoxifen 
Table 3 FDA and EMA drug description of anticancer drugs of lead compounds

\begin{tabular}{|c|c|c|c|c|c|c|c|}
\hline Drug & $\begin{array}{l}C_{\max } \text { Single oral dose (or otherwise as } \\
\text { indicated) }\end{array}$ & $\begin{array}{l}\mathrm{t}_{1 / 2} \text { Single oral dose (or } \\
\text { otherwise as indicated) }\end{array}$ & $\begin{array}{l}\mathrm{LD}_{50} \text { Single oral } \\
\text { dose toxicity }\end{array}$ & Indication & $\begin{array}{l}\text { Mechanism } \\
\text { of action }\end{array}$ & Dosage & $\begin{array}{l}\text { Reference } \\
\text { (health } \\
\text { agency) }\end{array}$ \\
\hline \multirow[t]{2}{*}{$\begin{array}{l}\text { Afatinib } \\
\text { (GlOTRIF甲) }\end{array}$} & NA & $\begin{array}{l}37 \mathrm{~h} \text { (after repeated dosing given } \\
\text { to patients) }\end{array}$ & NA & \multirow[t]{2}{*}{$\begin{array}{l}\text { Metastatic non-small } \\
\text { cell lung cancer }\end{array}$} & \multirow{2}{*}{$\begin{array}{l}\text { Irreversible inhibitor } \\
\text { of tyrosine kinase } \\
\text { autophos-phorylation }\end{array}$} & \multirow[t]{2}{*}{40 mg/day } & FDA \\
\hline & $\begin{array}{l}397 \mathrm{nmol} / \mathrm{l}(1 \times 8 \mathrm{mg} / \mathrm{kg} \\
\text { given to rats) }\end{array}$ & $4.5 \mathrm{~h}$ ( $1 \times 8 \mathrm{mg} / \mathrm{kg}$ given to rats) & $\begin{array}{l}382-763 \mathrm{mg} / \mathrm{kg} \\
\text { (mice) }\end{array}$ & & & & EMA \\
\hline \multirow[t]{2}{*}{$\begin{array}{l}\text { Bosutinib } \\
\text { (BOSULIF⿻) }\end{array}$} & $\begin{array}{l}0.2 \mu \mathrm{g} / \mathrm{ml} \text { ( } 500 \mathrm{mg} \text { given to } \\
\text { patients on } 15 \text { consecutive days) }\end{array}$ & $\begin{array}{l}22 \mathrm{~h} \text { (patients; dose not } \\
\text { indicated) }\end{array}$ & NA & \multirow{2}{*}{$\begin{array}{l}\text { Chronic, accelerated, } \\
\text { or blast phase } \mathrm{Ph}+\text { chronic } \\
\text { myelogenous leukemia }\end{array}$} & \multirow[t]{2}{*}{$\begin{array}{l}\text { Tyrosine kinase } \\
\text { inhibitor }\end{array}$} & \multirow[t]{2}{*}{$500 \mathrm{mg} /$ day } & FDA \\
\hline & NA & $\begin{array}{l}2.5-5.4 \mathrm{~h} \text { (mice and rats; dose } \\
\text { not indicated) }\end{array}$ & $\begin{array}{l}>2000 \mathrm{mg} / \mathrm{kg} \\
\text { (mice and rats) }\end{array}$ & & & & EMA \\
\hline \multirow[t]{2}{*}{$\begin{array}{l}\text { Crizotinib } \\
\left(\text { XALKORI }^{\oplus}\right)\end{array}$} & $\begin{array}{l}100-135 \mathrm{ng} / \mathrm{ml}(250 \mathrm{mg} \\
\text { given to patients) }\end{array}$ & $42 \mathrm{~h}$ (250 mg given to patients) & $>500 \mathrm{mg} / \mathrm{kg}$ (rats) & \multirow[t]{2}{*}{$\begin{array}{l}\text { Metastatic non-small } \\
\text { cell lung cancer }\end{array}$} & \multirow[t]{2}{*}{$\begin{array}{l}\text { Tyrosine kinase } \\
\text { inhibitor }\end{array}$} & \multirow[t]{2}{*}{$2 \times 250$ mg/day } & FDA \\
\hline & NA & $\begin{array}{l}5.8-13 \mathrm{~h} \text { (rats; dose not } \\
\text { indicated) }\end{array}$ & NA & & & & EMA \\
\hline \multirow[t]{2}{*}{$\begin{array}{l}\text { Gefitinib } \\
\left.\text { (IRESSA }{ }^{\oplus}\right)\end{array}$} & NA & $\begin{array}{l}48 \mathrm{~h} \text { (healthy volunteers; dose } \\
\text { not indicated) }\end{array}$ & NA & \multirow[t]{2}{*}{ Non-small cell lung cancer } & \multirow[t]{2}{*}{$\begin{array}{l}\text { Multiple tyrosine kinase } \\
\text { inhibitor }\end{array}$} & \multirow[t]{2}{*}{$250 \mathrm{mg} /$ day } & FDA \\
\hline & $\begin{array}{l}1 \mu \mathrm{g} / \mathrm{ml} \text { (after } 20 \mathrm{mg} / \mathrm{kg} \text { given } \\
\text { to rats); } 0.1 \mu \mathrm{g} / \mathrm{ml} \text { (after } 250 \mathrm{mg} / \mathrm{kg} \\
\text { given to healthy volunteers) }\end{array}$ & $\begin{array}{l}10 \mathrm{~h} \text { (rats; dose not indicated); } \\
30 \mathrm{~h} \text { (after } 250 \mathrm{mg} / \mathrm{kg} \text { given to } \\
\text { healthy volunteers) }\end{array}$ & $\begin{array}{l}\text { Around } 2000 \\
\mathrm{mg} / \mathrm{kg}(\mathrm{rats})_{i}> \\
1000 \mathrm{mg} / \mathrm{kg} \text { (dogs) }\end{array}$ & & & & EMA \\
\hline \multirow[t]{2}{*}{$\begin{array}{l}\text { Ponatinib } \\
\text { (INCLUSIG })\end{array}$} & $\begin{array}{l}6 \mathrm{~h} \text { (patients; dose } \\
\text { not indicated) }\end{array}$ & $\begin{array}{l}24 \mathrm{~h} \text { (patients; dose not } \\
\text { indicated) }\end{array}$ & $\begin{array}{l}>2000 \mathrm{mg} / \mathrm{kg} \\
\text { (mice) }\end{array}$ & \multirow[t]{2}{*}{ Chronic myeloid leukemia } & \multirow[t]{2}{*}{$\begin{array}{l}\text { Tyrosine kinase } \\
\text { inhibitor }\end{array}$} & \multirow[t]{2}{*}{45 mg/day } & FDA \\
\hline & $\begin{array}{l}4 \mathrm{~h} \text { (patients; dose } \\
\text { not indicated) }\end{array}$ & $\begin{array}{l}22 \mathrm{~h} \text { (patients; dose not } \\
\text { indicated) }\end{array}$ & NA & & & & EMA \\
\hline \multirow[t]{2}{*}{$\begin{array}{l}\text { Regorafenib } \\
\text { (STIVAGRA }^{\oplus} \text { ) }\end{array}$} & $\begin{array}{l}12.5 \mu \mathrm{g} / \mathrm{ml} \text { (after } 160 \mathrm{mg} \\
\text { given to patients) }\end{array}$ & $\begin{array}{l}24 \mathrm{~h} \text { (after } 160 \mathrm{mg} \\
\text { given to patients) }\end{array}$ & NA & \multirow[t]{2}{*}{ Metastatic colon cancer } & \multirow[t]{2}{*}{$\begin{array}{l}\text { Multiple protein kinase } \\
\text { inhibitor }\end{array}$} & \multirow[t]{2}{*}{$\begin{array}{l}160 \mathrm{mg} / \text { day for } \\
\text { first } 21 \text { days of a } \\
28 \text {-day cycle }\end{array}$} & FDA \\
\hline & $\begin{array}{l}3.96 \text { mg/l (multiple treatment: } 160 \\
\text { mg/day for } 3 \text { weeks given to patients) }\end{array}$ & $\begin{array}{l}2 \mathrm{~h} \text { (multiple treatment; } 160 \\
\mathrm{mg} / \text { day for } 3 \text { weeks given } \\
\text { to patients) }\end{array}$ & $\begin{array}{l}>250 \mathrm{mg} / \mathrm{kg} \\
\text { (mice and rats) }\end{array}$ & & & & EMA \\
\hline \multirow[t]{2}{*}{$\begin{array}{l}\text { Sorafenib } \\
\left(\text { NEXAVAR }^{\oplus}\right)\end{array}$} & NA & $25-48 \mathrm{~h}$ & NA & \multirow[t]{2}{*}{ Liver, kidney, thyroid cancer } & \multirow[t]{2}{*}{$\begin{array}{l}\text { Multiple protein kinase } \\
\text { inhibitor }\end{array}$} & \multirow[t]{2}{*}{$2 \times 400 \mathrm{mg} /$ day } & FDA \\
\hline & $\begin{array}{l}0.55 \mathrm{mg} / \mathrm{l} \text { (after } 400 \mathrm{mg} \text { given } \\
\text { to patients) }\end{array}$ & $\begin{array}{l}22.3 \mathrm{~h} \text { (after } 400 \mathrm{mg} \text { given to } \\
\text { patients) }\end{array}$ & $\begin{array}{l}>1460 \mathrm{mg} / \mathrm{kg} \\
\text { (mice and rats) }\end{array}$ & & & & EMA \\
\hline \multirow[t]{2}{*}{$\begin{array}{l}\text { Sunitinib } \\
\text { (SUTENT }^{\oplus} \text { ) }\end{array}$} & NA & $\begin{array}{l}40-60 \mathrm{~h} \text { (parent drug in healthy } \\
\text { volunteers; } 80-110 \mathrm{~h} \text { (active } \\
\text { metabolite in healthy volunteers } \\
\text { (dose not indicated) }\end{array}$ & NA & \multirow[t]{2}{*}{$\begin{array}{l}\text { Gastrointestinal stromal } \\
\text { tumor, renal cell carcinoma, } \\
\text { well-differentiated pancreatic } \\
\text { neuroendocrine tumors }\end{array}$} & \multirow[t]{2}{*}{$\begin{array}{l}\text { Inhibitor of multiple } \\
\text { receptor tyrosine } \\
\text { kinases }\end{array}$} & \multirow[t]{2}{*}{$\begin{array}{l}50 \mathrm{mg} / \mathrm{d} \text { for the } \\
\text { first } 28 \text { days of a } \\
42 \text {-day cycle }\end{array}$} & FDA \\
\hline & NA & NA & $\begin{array}{l}>500 \mathrm{mg} / \mathrm{kg} \\
\text { (mice and rats) }\end{array}$ & & & & EMA \\
\hline $\begin{array}{l}\text { Trametinib } \\
\left(\text { (MEKINIST }^{\oplus)}\right.\end{array}$ & NA & $\begin{array}{l}\text { Estimated: } 3.9-4.8 \text { days } \\
\text { (patients; dose not indicated) }\end{array}$ & NA & & Kinase inhibitor & 2 mg/day & FDA \\
\hline
\end{tabular}


Table 3 FDA and EMA drug description of anticancer drugs of lead compounds (Continued)

\begin{tabular}{|c|c|c|c|c|c|c|c|}
\hline & $\begin{array}{l}22.2 \mathrm{ng} / \mathrm{ml} \text { (steady state after } 2 \\
\mathrm{mg} / \text { daygiven to healthy volunteers) }\end{array}$ & $\begin{array}{l}5.3 \text { days (healthy volunteers; } \\
\text { dose not indicated) }\end{array}$ & NA & $\begin{array}{l}\text { Unresectable or metastatic } \\
\text { melanoma with BRAF V600E } \\
\text { or V600K mutations }\end{array}$ & & & EMA \\
\hline \multirow[t]{2}{*}{$\begin{array}{l}\text { Tamoxifen citrate } \\
\left(\text { NOLVADEX }^{\oplus}\right)\end{array}$} & $40 \mathrm{ng} / \mathrm{ml}$ (after $20 \mathrm{mg}$ given to rats) & $\begin{array}{l}5-6 \text { days (after } 20 \mathrm{mg} \\
\text { given to rats) }\end{array}$ & NA & Breast cancer & $\begin{array}{l}\text { Nonsteroidal } \\
\text { antiestrogen }\end{array}$ & NA & FDA \\
\hline & NA & NA & NA & & & 20 mg/day & EMA \\
\hline \multirow[t]{2}{*}{$\begin{array}{l}\text { Vandetanib } \\
\left.\text { (CAPRELSA }^{\circledR}\right)\end{array}$} & NA & NA & NA & Medullary thyroid cancer & $\begin{array}{l}\text { Multiple tyrosine kinase } \\
\text { inhibitor }\end{array}$ & 300 mg/day & FDA \\
\hline & NA & $\begin{array}{l}19 \text { days (after } 300 \mathrm{mg} \text { given to } \\
\text { healthy volunteers) }\end{array}$ & NA & & & & EMA \\
\hline
\end{tabular}
healthy volunteers)

NA Not available on the data sheets of the according health agency 
compounds characterized by an $\mathrm{IC}_{50} \leq 10 \mu \mathrm{M}$ against both stages in order to select good in vivo candidates. With regards to potential drug exposure time, vandetanib has a very long half-life (19 days in humans), which we considered an advantageous feature for killing parasites that reside in the bloodstream.

\section{Activity in S. mansoni-infected mice}

Afatinib, bosutinib, ponatinib, sunitinib, trametinib, and vandetanib were chosen for in vivo studies based on their in vitro activity against schistosomes, and review of the literature. Of note, since crizotinib was not affordable, it was not tested in vivo. Drugs were orally applied to mice in a single dose of $400 \mathrm{mg} / \mathrm{kg}$ body weight; except for afatinib, which was administered at a single dose of $200 \mathrm{mg} / \mathrm{kg}$, given its lower $\mathrm{LD}_{50}$. Trametinib, and vandetanib had the highest WBRs of $63.6 \%$, and $48.1 \%$ respectively ( $p$-value $>0.05$ ). The remaining compounds were only marginally, or not at all efficacious, with WBRs between 0-27.5 \% (Table 4).

\section{Discussion}

New drugs are needed to treat the neglected tropical disease schistosomiasis. In the present work, we applied a repurposing strategy using a set of FDA-approved anticancer drugs. This library was chosen given proposed overlaps in mechanism of action, active pharmacophores, and matches of human drug targets found in the genome of $S$. mansoni $[6,11,16]$.

Because repurposing builds upon previous research and development efforts, new antischistosomal drugs could quickly advance into clinical testing, greatly diminishing the huge costs of drug development [5]. However, it is worth reflecting on the selected library. Anticancer agents are often characterized by the occurrence of numerous and severe adverse events. Since anthelmintic chemotherapy consists typically of a single dose [17], the adverse events occurring during the intensive multiple-dose regimens of

Table 4 In vivo worm burden reductions after a single oral dose of $200 \mathrm{mg} / \mathrm{kg}$ (afatinib) or $400 \mathrm{mg} / \mathrm{kg}$ body weight (remaining drugs) to mice harboring a chronic S.mansoni infection

\begin{tabular}{llll}
\hline Drug & Number of mice treated & $\begin{array}{l}\text { Average worm } \\
\text { count (SD) }\end{array}$ & WBR [\%] \\
\hline Control $^{1}$ & 8 & $20.4(12.4)$ & - \\
Control $^{2}$ & 8 & $23.0(18.4)$ & - \\
Trametinib $^{1,2}$ & 5 & $8.1(4.1)$ & 63.6 \\
Vandetanib $^{1,2}$ & 5 & $11.3(8.4)$ & 48.1 \\
Afatinib $^{1}$ & 4 & $14.8(11.1)$ & 27.5 \\
Ponatinib $^{1}$ & 3 & $16.6(12.9)$ & 18.6 \\
Sunitinib $^{1}$ & 4 & $22.5(8.5)$ & 2.2 \\
Bosutinib $^{1}$ & 4 & $25.3(4.0)$ & 0 \\
\hline
\end{tabular}

$P$ value of all WBRs was $>0.05$; Values in superscript refer to the corresponding control group

$S D$ standard deviation cancer chemotherapy [18], would probably not occur. This encourages studying the anthelmintic properties of anticancer drugs further and in more detail. However, the health-risk benefits of repurposing cancer drugs should be evaluated on a case-by-case basis.

We identified 11 cancer drugs in this work with high in vitro activity against adult and larval $S$. mansoni. It is worth highlighting that 10 of these drugs are protein kinase inhibitors, which have been suggested as potentially interesting antischistosomal drug discovery candidates, since protein kinase inhibitors can interfere with signaling pathways in schistosome development [6]. The exact mechanism(s) of action of these drugs on schistosomes remain yet to be elucidated, although apoptosis might be involved, due to the fact that many protein kinase inhibitors induce apoptosis [19].

Six of these compounds maintained their antischistosomal activity when exposed to serum albumin - the predominant plasma protein in humans [14] - while the antischistosomal activity of 5 lead candidates was strongly negatively influenced by serum albumin. The loss of in vitro antischistosomal activity of imatinib (a protein kinase inhibitor, which did not progress further in our screens) in the presence of alpha-1-acid glycoprotein, serum albumin, and especially with a combination of both, has been described recently [20]. The influence of alpha-1acid glycoprotein on the in vitro activity of our lead compounds was not studied in the present work since binding to this protein might play a more crucial role in rodents than in humans, as described below.

In vivo drug efficacy determination, based on our in vitro findings (taking into account the loss of activity in the presence of albumin), as well as a literature review on preclinical and clinical data of these drugs (Table 3), revealed two kinase inhibitors: trametinib, and vandetanib, with moderate WBRs of 63.6 and $48.1 \%$ respectively. Vandetanib's efficacy was somewhat surprising, since the addition of albumin to the in vitro $\mathrm{IC}_{50}$ determination led to inactivity of the drug. Protein binding to serum albumin, and apha-1acid glycoprotein (90\%) was also highlighted by the manufacturer [21]. However, trametinib and vandetanib have a high bioavailability of $100 \%$ [22], or > $90 \%$ [23] in rodents. Additionally, both drugs have long halflives: 3 days in rats and mice for trametinib [24]; and $28 \mathrm{~h}$ in mice for vandetanib [25]. In humans, both trametinib and vandetanib also have exceptionally long half-lives: 4.2 days ( $3.9-4.5$ days) [26], and 19 days [27] respectively. The high bioavailabilities combined with the long half-lives might therefore outweigh the negative influence of protein binding on the antischistosomal activity, and explain the efficacy against $S$. mansoni in the mouse model. There might even be a possibility for higher efficacy of vandetanib in humans, since the alpha-1-acid glycoprotein homeostasis is species-dependent. While this serum protein in humans 
increases $2-5$-fold upon inflammatory processes, the increase in mice is $30-40$-fold, which is a crucial difference when alpha1-acid glycoprotein-sensitive drugs are being evaluated [16].

Interestingly, none of the 14 drugs, for which the genes of the corresponding human drug targets also exists in $S$. mansoni [11], revealed noteworthy antischistosomal activity $\left(\mathrm{IC}_{50}>33.3 \mu \mathrm{M}\right)$ (data not shown). Only temsirolimus, and sirolimus killed NTS within 24 or 48 h respectively; but neither of the two reduced the viability of adult $S$. mansoni considerably. However, we would like to highlight that our drug activity assessments are based on alterations on the parasite phenotype. We did not determine the effect on schistosome development, such as the reproductive organs, or egg production and expulsion, which might be affected by the 14 drugs.

When comparing our in vitro results with those of other research groups, differences in drug activity are notable. Under our screening conditions, at $33.3 \mu \mathrm{M}$, and $72 \mathrm{~h}$ drug exposure, imatinib showed $<70 \%$ activity against schistosomula, and $76 \%$ against adult schistosomes, while all worms were still moving. In contrast, Beckmann and Grevelding (2010) described the activity of imatinib (72 h postincubation) to be fatal for $30 \%$ of all adult worms after incubation at $10 \mu \mathrm{M}$, or $63 \%$ after incubation at $50 \mu \mathrm{M}$ [6]. According to Katz et al (2013), $6 \%$ of worms died after incubation with imatinib $(25 \mu \mathrm{M}$ for $24 \mathrm{~h})$, followed by $48 \mathrm{~h}$ in drug-free culture medium [28]. The reason for the different survival rate is not clear, but might originate from differences in drug susceptibilities of different S. mansoni strains (Puerto Rican; Luiz Evangelista versus Liberian).

\section{Conclusion}

In summary, the oncology drug set revealed several in vitroactive drugs against S. mansoni; of which two (trametinib, and vandetanib) were also moderately active in vivo. There is room to further investigate trametinib's and vandetanib's potential as antischistosomal drugs, including elucidation of mechanisms of action, application of different treatment courses, and structure-activity relationship studies.

\section{Competing interests}

Both authors declare that they have no competing interests.

\section{Authors' contributions}

NC and JK designed the studies. NC carried out the experiments and wrote the first draft of the manuscript. JK revised the manuscript. Both authors read and approved the final version of the manuscript.

\section{Acknowledgements}

We are grateful to the European Research Council (ERC-2013-CoG 614739-A_HERO to J.K.) and the Freiwillige Akademische Gesellschaft (FAG) Basel for financial support.

Received: 18 June 2015 Accepted: 29 July 2015

Published online: 13 August 2015

\section{References}

1. Colley DG, Bustinduy AL, Secor WE, King CH. Human schistosomiasis. Lancet. 2014;384:1094-5.

2. Murray CJL, Vos T, Lozano R, Naghavi M, Flaxman AD, Michaud C, et al. Disability-adjusted life years (DALYs) for 291 diseases and injuries in 21 regions, 1990-2010: a systematic analysis for the Global Burden of Disease Study 2010. Lancet. 2012;380:2197-223.

3. Pedrique B, Strub-Wourgaft N, Some C, Olliaro P, Trouiller P, Ford N, et al. The drug and vaccine landscape for neglected diseases (2000-11): a systematic assessment. Lancet Glob Health. 2013;1:e371-379.

4. Knopp S, Becker SL, Ingram KJ, Keiser J, Utzinger J. Diagnosis and treatment of schistosomiasis in children in the era of intensified control. Expert Rev Anti Infect Ther. 2013;11:1237-58.

5. Panic G, Duthaler U, Speich B, Keiser J. Repurposing drugs for the treatment and control of helminth infections. Int J Parasitol Drugs Drug Resist. 2014:4:185-200.

6. Dissous C, Grevelding CG. Piggy-backing the concept of cancer drugs for schistosomiasis treatment: a tangible perspective? Trends Parasitol. 2011;27:59-66.

7. Beckmann S, Grevelding CG. Imatinib has a fatal impact on morphology, pairing stability and survival of adult Schistosoma mansoni in vitro. Int J Parasitol. 2010;40:521-6.

8. Doerig C, Grevelding CG. Targeting kinases in Plasmodium and Schistosoma: same goals, different challenges. Biochim Biophys Acta. 2015. doi:10.1016/j.bbapap.2015.03.002.

9. Ingram-Sieber K, Cowan N, Panic G, Vargas M, Mansour NR, Bickle QD, et al. Orally active antischistosomal early leads identified from the open access malaria box. PLoS Negl Trop Dis. 2014;8:e2610.

10. Cowan N, Dätwyler P, Ernst B, Wang C, Vennerstrom JL, Spangenberg T, et al. Activity of N, N'-diarylurea MMV665852 analogs against Schistosoma mansoni. Antimicrob Agents Chemother. 2015;59:1935-41.

11. Berriman M, Haas BJ, LoVerde PT, Wilson RA, Dillon GP, Cerqueira GC, et al. The genome of the blood fluke Schistosoma mansoni. Nature. 2009;460:352-8.

12. Xiao S-H, Keiser J, Chollet J, Utzinger J, Dong Y, Endriss Y, et al. In vitro and in vivo activities of synthetic trioxolanes against major human schistosome species. Antimicrob Agents Chemother. 2007;51:1440-5.

13. Manneck T, Haggenmüller $Y$, Keiser J. Morphological effects and tegumental alterations induced by mefloquine on schistosomula and adult flukes of Schistosoma mansoni. Parasitology. 2010;137:85-98.

14. Fasano M, Curry S, Terreno E, Galliano M, Fanali G, Narciso P, et al. The extraordinary ligand binding properties of human serum albumin. IUBMB Life. 2005;57:787-96.

15. European Medicines Agency (EMA): CHMP assessment report for GIOTRIF ${ }^{\circledast}$ (afatinib). [http://www.ema.europa.eu/docs/en_GB/document_library/ EPAR_-_Public_assessment_report/human/002280/WC500152394.pdf]

16. Gelmedin V, Dissous C, Grevelding CG. Re-positioning protein-kinase inhibitors against schistosomiasis. Future Med Chem. 2015;7:737-52.

17. WHO: Preventive Chemotherapy in Human Helminthiasis: Coordinated Use of Anthelminthic Drugs in Control Interventions: A Manual for Health Professionals and Programme Managers. 2006. [http://whqlibdoc.who.int/ publications/2006/9241547103_eng.pdf]

18. Calabresi P and Parks RE. Chemotherapy of neoplastic diseases. In: Goodman Gilman A, Goodman LS, Rall TW, Murad F, editors. Goodman and Gilman's. The pharmacological basis of therapeutics, 7th ed. New York: MacMillan; 1985. p. 1240-1307.

19. Lee EF, Fairlie WD. Repurposing apoptosis-inducing cancer drugs to treat schistosomiasis. Future Med Chem. 2015;7:707-11.

20. Beckmann S, Long T, Scheld C, Geyer R, Caffrey CR, Grevelding CG. Serum albumin and a-1 acid glycoprotein impede the killing of Schistosoma mansoni by the tyrosine kinase inhibitor Imatinib. Int J Parasitol Drugs Drug Resist. 2014:4:287-95.

21. AstraZeneca: Highlights of prescribing information for CAPRELSA ${ }^{\oplus}$ (vandetanib) tablets. 2011. [http://www1.astrazeneca-us.com/pi/ vandetanib.pdf]

22. Center for drug evaluation and research. Food and Drug Administration: Pharmacology review(s), MEKINIST ${ }^{\oplus}$ (trametinib), Reference ID: 3298856. 2013. [http://www.accessdata.fda.gov/drugsatfda_docs/nda/2013/ 2041140rig1s000PharmR.pdf]

23. Center for drug evaluation and research. Food and drug administration: Pharmacology review(s), vandetanib, Reference ID: 2923639. 2011. [http:// 
www.accessdata.fda.gov/drugsatfda_docs/nda/2011/

022405orig1s000pharmr.pdf]

24. Gilmartin AG, Bleam MR, Groy A, Moss KG, Minthorn EA, Kulkarni SG, et al. GSK1120212 (JTP-74057) is an inhibitor of MEK activity and activation with favorable pharmacokinetic properties for sustained in vivo pathway inhibition. Clin Cancer Res Off J Am Assoc Cancer Res. 2011:17:989-1000.

25. Gustafson DL, Bradshaw-Pierce EL, Merz AL, Zirrolli JA. Tissue distribution and metabolism of the tyrosine kinase inhibitor ZD6474 (Zactima) in tumorbearing nude mice following oral dosing. J Pharmacol Exp Ther. 2006;318:872-80

26. GlaxoSmithKline: Highlights of prescribing information for MEKINIST ${ }^{\odot}$ (trametinib) tablets. [http://www.accessdata.fda.gov/drugsatfda_docs/label/ 2013/204114s000lbl.pdf]

27. AstraZeneca: Summary of product characteristics CAPRELSA . [http://www.ema.europa.eu/docs/en_GB/document_library/EPAR__Product_Information/human/002315/WC500123555.pdf]

28. Katz N, Couto FFB, Araújo N. Imatinib activity on Schistosoma mansoni. Mem Inst Oswaldo Cruz. 2013;108:850-3.

\section{Submit your next manuscript to BioMed Central and take full advantage of:}

- Convenient online submission

- Thorough peer review

- No space constraints or color figure charges

- Immediate publication on acceptance

- Inclusion in PubMed, CAS, Scopus and Google Scholar

- Research which is freely available for redistribution 